\title{
REPRESENTASI PENINDASAN GANDA DALAM NOVEL MIRAH DARI BANDA BERDASARKAN PERSPEKTIF FEMINISME POSKOLONIAL
}

\author{
Awla Akbar Ilma \\ Alumni S2 Ilmu Sastra Universitas Gadjah Mada
}

\begin{abstract}
Abstrak
Penelitian ini secara khusus mengkaji bentuk-bentuk penindasan ganda yang terdapat dalam novel Mirah dari Banda berdasarkan perspektif feminisme poskolonial. Hasil analisis menunjukkan bahwa novel mewacanakan kedudukan inferior perempuan akibat dominasi sistem kolonialisme Belanda dan Jepang serta dominasi patriarki baik lelaki kolonial maupun pribumi. Melalui dua bentuk penindasan demikian, perempuan pribumi menderita dan berada di level terendah dalam situasi kolonial. Terkait dengan waktu penerbitannya, yakni tahun 1980 novel Mirah dari Banda termasuk novel nostalgia atas penindasan dan perjuangan melawan kolonialisme. Sikap nostalgia demikian sekaligus dapat dianggap sebagai refleksi atas kemungkinan hadirnya penindasan-penindasan ganda terhadap perempuan saat ini yang identik dengan era kapitalisme (imperialisme) dan masih mengakarnya ideologi patriarki.
\end{abstract}

Kata Kunci: Mirah dari Banda, perempuan, penindasan ganda, nostalgia.

\begin{abstract}
This study specifically examines the multiple forms of oppression that is found in the novel Mirah dari Banda by postcolonial feminist perspective. The analysis showed that the novel talk about inferior position of women as a result of the dominance of Dutch and Japanese colonial system and patriarchal domination both colonial and indigenous men. With the two forms of oppression Thus, indigenous women suffer and the lowest level in a colonial situation. Associated with the time of publication, the 1980 novel Mirah dari Banda include nostalgia novel of oppression and the struggle against colonialism. Thus at the same nostalgic attitude can be regarded as a reflection on the possibility of the presence of the double oppression of women today which synonymous with the era of capitalism (imperialism) and still rooted patriarchal ideology.
\end{abstract}

Keywords: Mirah dari Banda, women, double oppression, nostalgia.

\section{Pendahuluan}

Gender dan ketidaksetaraan hingga kini masih terus menjadi persoalan penting meskipun perjuangan kesetaraan telah dilakukan ribuan tahun di berbagai tempat. Jika kita menengok ke belakang, Madame Bovoir, Lady Mary, Wartley Montega dapat dikatakan beberapa perempuan yang berupaya memulai kesadaran akan menjadi perempuan. Nilai-nilai universalitas yang dikemukakan pada zaman pencerahan, filsafat perubahan politik abad 17 dan 18, serta hadirnya revolusi Prancis dan Amerika menginspirasi pandangannya untuk melihat posisi perempuan dalam relasinya dengan laki-laki. Aspek biologis dipandang menjadi masalah fundamental hadirnya diskriminasi dan penindasan perempuan dalam sistem budaya patriarki. Pandangan ini secara signifikan memulai kesadaran untuk tidak menjadikan alasan seks sebagai halangan untuk melibatkan diri dalam sektor publik.

Beranjak dari tahun yang terlalu lampau, di era 60-an era, dimana konsep demokrasi mulai hadir, muncul kesadaran lebih lanjut bahwa perempuan masih berada dalam ketidakadilan sosial. Selesainya perang dunia dan kebebasan politik hak-hak sipil bagi perempuan tidak dirasa membebaskan dirinya untuk keluar menuju sektor publik dan memperoleh hak-hak ekonomis secara nyaman. Dipengaruhi oleh filsafat dekontruksi, logosentrisme laki-laki dalam oposisi biner coba dilihat secara kritis. Tokoh-tokoh seperti Helena Civous dan Julius Kristeva kemudian melihat bahwa gender telah dikontruksi secara sosial oleh kuasa laki-laki melalui tata cara hegemonik sehingga muncul kesepakatan akan ketertundukan perempuan.

Di era 80 dan 90-an, era dimana 


\section{Jurnal Poetika Vol. IV No. 1, Juli 2016}

posmodernisme tumbuh secara pesat, muncul pemikiran dan gerakan feminis yang melihat problem kesetaraan sebagai problem konteksual yang terkait dengan posisi dan keberadaan perempuan yang berbeda-beda. Tokoh-tokoh seperti Gayatri Spivak, Mohantly, dan Corby berupaya untuk menjembatani sisi ini sebagai paham partikularitas dari sebuah problematika. Spivak misanya, ia melihat bahwa teks sastra barat tidak memiliki kesadaran akan efek-efek kolonialisme terutama terhadap perempan-perempuan di negara dunia ketiga. Sementara Corby melihat bahwa patriarki dan opresi perempuan terkait dengan pengalaman penindasan yang berhubungan dengan perbedaan budaya. Artinya, problem tidak berdasarkan koridor deterministik biologis semata, melainkan juga sosial dan kultural. Sehingga faktor-faktor seperti kelas, ras, etnis, mempengaruhi makna, ekspresi dan pengalaman gender.

Penjelasan terakhir ini memiliki signifikasi nyata dengan konteks Indonesia. Fakta historis sebagai negeri terjajah dalam beberapa hal masih memunculkan pengalaman-pengalaman kolonialisme. Ketertindasan serta inferiorisasi menjadi aspek yang selalu muncul dalam setiap obrolan, refleksi, yang tidak hanya tampak dalam wujud fisik, namun juga dalam tataran abstrak, terutama dalam ruang representasi kebudayaan. Menarik untuk disimak, terlepasnya Indonesia dari belenggu kolonial memunculkan ekspresi atas pengalaman secara lebih leluasa. Novelnovel yang secara nyata menunjukkan visi demikian, misalnya novel Njai Mirdja karya J. Kleian (1983), Bumi Manusia (1980) dan Anak Semua Bangsa (1980) karya Pramoedya Ananta Toer, Ca Bau Kan (1999) dan Kembang Jepun (2006) karya Remy Sylado, Kadarwati Wanita dengan Lima Nama karya Pandir Kelana (1982) dan sebagainya. Sementara itu, salah satu novel yang muncul di era "pascakolonial" yang menggambarkan pengalaman perempuan pada masa kolonial secara menyeluruh dari Era Belanda hingga Jepang adalah novel Mirah dari Banda (MdB) karya Hanna Rambe.

Secara singkat, novel $M d B$ merupakan novel yang menggambarkan kedudukan inferior perempuan di Kepulauan Banda pada masa kolonialisme Belanda dan Jepang. Kedudukan tersebut muncul akibat dari penindasan ganda yang mereka alami berupa kewajibannya sebagai seorang pribumi yang harus tunduk terhadap kekuasaan Belanda dan kewajiban untuk tunduk kepada laki-laki kolonial dan bahkan pribumi melalui kedudukannya sebagai pemuas nafsu seksual. Sementara pada masa kolonial Jepang, para perempuan dominan didudukkan sebagai hasrat pemuas hasrat seksual militer Jepang.

Untuk melihat bagaimana bentuk kekerasan yang terjadi dalam novel $M d B$ terkait situasi kolonialisme, tulisan ini berupaya membicarakannya melalui perspektif teori feminisme pascakolonial. Teori ini akan merujuk pada asumsi penindasan ganda, baik sistem kolonial, lelaki kolonial, maupun lelaki pribumi. Sementara itu, pembahasan selanjutnya yang akan dipaparkan dalam tulisan ini ialah maksud dan gagasan yang melatarbelakangi hadirnya novel $M d B$ di era pascakolonial ini.

\section{Teori Feminisme Poskolonial}

Dalam memandang ketidakadilan gender, teori poskolonial menganggap bahwa kaum perempuan, terutama di Dunia Ketiga, telah menanggung beban penindasan ganda: dari bangsa kolonial dan dari kaum lelaki pribumi. Poskolonialisme mempostulatkan "Perempuan di Dunia Ketiga" sebagai korban par excellence -korban dari ideologi imperial dan patriarki pribumi ataupun patriarki asing yang terlupakan (Gandhi, 2007:xi;108).

Bentuk ketidakadilan gender terhadap perempuan Dunia Ketiga ini berkaitan dengan landasan praktik kolonial yang lahir dari pandangan dunia yang percaya terhadap superioritas mutlak manusia terhadap bukan manusia atau sub-manusia, laki-laki terhadap perempuan, dan modern atau progresif terhadap tradisional atau biadab. Sehubungan dengan itu, penjajah membedakan laki-laki dengan perempuan dan bertindak sesuai dengan pembedaan itu. Laki-laki menjadi target umum kebijakan sehingga mereka selalu 


\section{Jurnal Poetika Vol. IV No. 1, Juli 2016}

diperhitungkan dalam berbagai hal. Proses penjajahan tersebut tetap akan membedakan jenis kelamin sejauh penjajah berjenis kelamin laki-laki dan menggunakan identitas gender untuk membatasi kebijakan.

Pada dasarnya dalam situasi kolonial terdapat hierarki empat kategori- bukan dua. Puncak hierarki diduduki oleh laki-laki (Eropa), perempuan (Eropa), bumiputra (laki-laki negeri jajahan), dan liyan (perempuan negeri jajahan). Berdasarkan posisi tersebut perempuan negeri jajahan dijajah oleh orang-orang Eropa sebagai warga negeri jajahan dan sebagai perempuan negeri jajahan. Mereka didominasi, dieksploitasi, dan diinferiorisasi sebagai warga negeri jajahan bersama dengan laki-laki negeri jajahan dan kemudian secara terpisah diinferiorisasi dan dimarjinalisasi sebagai perempuan negeri jajahan (Oyewumi, 2005:340).

Dengan demikian, perempuan dalam masyarakat terjajah bahkan disebut sebagai sasaran-sasaran riil dari wacana-wacana kolonialis dan nasionalis. Jadi, meskipun sering terjadi perbedaan dan persaingan dalam memperebutkan perempuan pribumi, patriarki-patriarki kolonial dan pribumi tetap saling bekerja sama untuk menjaga agar kaum perempuan berada dalam posisi inferior (Loomba, 2003:286).

Berdasarkan penjelasan demikian penelitian ini menggunakan perpaduan antara teori poskolonial dengan teori feminisme. Secara praktik, teori feminisme poskolonial telah mengikuti jalur evaluasi yang konvergen, yaitu jalur yang memperhatikan dengan suatu kajian dan pertahanan "yang lain" yang terpinggirkan dalam struktur represif dominasi dan mengikuti jalan teoretis yang sangat serupa. Teori feminisme poskolonial yang serupa tersebut berusaha merespon hierarki gender, budaya, ras yang telah ada dan keduanya menjadi bagian dari postrukturalisme yang menolak oposisi biner terhadap kontruksi wewenang patriarki dan kolonialisme (Gandhi, 1998:107).

Cara kerja kritikisme feminis poskolonial berkaitan dengan ide, cara penilaian, cara pandang, dan cara mengimajinasikan (representasi) perempuan di negeri terjajah dan di tempat-tempat tertentu di Barat. Di satu pihak, pendekatan ini berkonsentrasi pada konstruksi perbedaan gender pada masa penjajahan, melalui wacana kolonial dan antikolonial. Di pihak lain, perhatian ditujukan pada representasi perempuan dalam wacana poskolonial dengan konsentrasi pokok pada karya-karya penulis perempuan (McLoed, 2000:172).

Sebagaimana diketahui, praktik pembacaan feminis berkaitan erat dengan kontestasi terhadap autoritas patriarkal. Dalam hal ini, patriarki mengacu pada sistem politik, material, dan imajinatif yang bertumpu pada kuasa laki-laki dan pemarjinalan perempuan. Patriarki memiliki kesejajaran dengan kolonialisme pada tataran konkret dan tataran imajinasi. Keduanya menegaskan sistem representasional yang menciptakan tatanan dunia yang disajikan kepada individu sebagai sesuatu yang normal dan benar. Sebagaimana kolonialisme, patriarki hadir pula dalam perlawanan terhadap kekuasaan. Berdasarkan kesejajaran itu, feminisme dan poskolonialisme memiliki tujuan yang sama, yaitu melawan penindasan (McLeod, 2000:174).

\section{Novel dan Ruang Representasi}

Novel merupakan karya seorang pengarang secara personal sebagai hasil komunikasi intensif terhadap lingkungan yang melingkupinya sehingga mampu menampilkan realitas yang terjadi bahkan yang tersembunyi. Meskipun demikian, novel tidak selamanya melihat realitas secara berimbang, melainkan mengandung kepentingan dan bahkan ruang tempat ideologi tertentu beroperasi. Dengan demikian, novel memiliki kekuatan untuk mengarahkan daya kognitif manusia pada serangkaian pemahaman melalui simbol dan tanda untuk kemudian membentuk sikap yang mengarahkan khalayaknya pada perilakuperilaku tertentu. Oleh karena itu, novel tepat diteliti dan ditempatkan sebagai ruang representasi untuk dibongkar dan dilihat secara seksama terkait kepentingan, maksud, dan 


\section{Jurnal Poetika Vol. IV No. 1, Juli 2016}

makna yang ingin dihadirkan di balik nuansa penggambarannya. Dalam membaca novel $M d B$ penelitian ini secara intensif menggunakan cara baca reading is a women untuk melihat bagaimana perempuan dihadirkan dalam teks.

\section{Novel Mirah dari Banda sebagai Representasi Penindasan Ganda}

Novel $M d B$ sebagai bagian dari kasusastraan Indonesia berupaya menggambarkan inferiorisasi kolonialisme Belanda terhadap perempuan pribumi. Dalam menggambarkannya novel $M d B$ menguraikan formasi-formasi sosial dan kultural perempuan terjajah dengan kedudukannya sebagai babu, nyai, dan kuli di perkebunan. Dalam profesi demikian mereka pun tak dapat lepas dari berbagai penindasan dan pelecehan seksual.

Sebagai babu, Tokoh Mirah memiliki kewajiban untuk mengurus urusan rumah tangga, mengurus Nyonya Besar, menyiapkan segala peralatan sebelum Noni berangkat sekolah, dan ia pun tidak diizinkan untuk beristirahat (Rambe, 2010:151,159). Dalam keseharian, ia selalu siap menerima perintah dan selalu duduk bersimpuh di lantai, sementara Nyonya Besar maupun anak-anaknya duduk di kursi rotan (Rambe, 2010:155). Dalam situasi ini, ia selalu mengalami tekanan dan ketakutan.

Sementara sebagai kuli, para perempuan dalam novel dituntut untuk bekerja keras di perkebunan. Jika mereka melakukan kesalahan dengan mengambil buah pala yang masih muda mereka akan terkena hukuman, yakni harus mencabuti rumput di rumah Tuan Besar dan tidak mendapat uang (Rambe, 2010:168). Prosedur jam kerja kerja mereka pun sangat ketat, dimulai dari pagi hari ketika masih gelap gulita hingga sore hari selama enam hari dalam seminggu (Rambe, 2010:169,142). Ironisnya sebagai kuli, para perempuan tidak dapat lepas dari pelecehan seksual. Praktik demikian nyata dilakukan Marinyo, mandor pribumi yang berasal dari Ambon, kepada tokoh Mirah.

Datanglah seorang laki-laki dari jauh. Saya tahu dia Marinyo, bawahan mandor dari perek kami. Hati saya berdebar-debar. Ia langsung menuju kepada saya dan membentak kenapa saya duduk-duduk sedangkan orang lain sibuk mengangkat pala...

Ia duduk di samping saya, di tanah. Saya bergeser, ia bergeser. Geser menggeser akhirnya kami bergumul. Saya tak ingat asal mulanya.

(halaman 187)

Praktik pergumulan yang ditunjukkan dalam kutipan di atas menunjukkan kuasa lelaki pribumi terhadap perempuan kuli. Tubuh perempuan kuli dianggap sebagai situs tempat kekuasaan patriarki tradisional berkuasa, mengingat pergumulan ini dilakukan oleh lelaki pribumi terhadap perempuan pribumi dalam situasi kolonialisme.

Bahkan ketika dewasa Mirah pun diangkat menjadi nyai oleh Tuan Besar. Dalam relasi pergundikan, seorang nyai akan mengalami berbagai penindasan, pengabaian, dan kekejaman seksual. Sebagai seorang nyai pekerjaan Mirah terpusat pada peran melayani suami. Hal itu terbukti melalui kutipan berikut.

Susahlah menjadi perempuan semacam saya ini. Ke sana kemari hanya alat. Alat pemuas nafsu Tuan Besar, alat pemeras dari para buruh kontrak yang dulu rekan saya di hutan pala.

(halaman 213-214)

Kondisi demikian menunjukkan bahwa Mirah tengah mengalami masa sulit berkepanjangan sebagai kuli dan nyai serta tidak bisa lepas dari kekerasan seksual. Ia tertindas oleh sistem kolonialisme dan sistem patriarki. Sebagai perempuan pribumi ia tertaklukan oleh lelaki pribumi dan lelaki kolonial. Dengan dominasi dari dua pihak -lelaki Belanda dan lelaki pribumi, budaya patriarki asing dan patriarki tradisional, kolonialisme dan patriarki- menunjukkan bahwa perempuan telah mengalami penindasan ganda sehingga ia semakin berada dalam posisi inferior, terbungkam tanpa memiliki ruang untuk berbicara. 


\section{Jurnal Poetika Vol. IV No. 1, Juli 2016}

Secara praktis, dominasi sistem kolonialisme dan patriarki dilakukan atas latar belakang ideologi kolonialisme yang bersifat maskulin dan pandangan liyan terhadap perempuan pribumi. Dalam teori poskolonial, liyan diartikan sebagai subjek yang dibedakan atau dimarginalkan karena wacana imperial dan kolonial. Keliyanan tersebut dibentuk oleh wacana yang membedakan pusat imperial atau kolonial dengan pribumi (Ashcroft, 1998:170). Sebagai liyan, perempuan pribumi dianggap sebagai pihak yang irasional, primitif, bodoh, pemalas, kulit gelap, pantas menjadi budak, dan sebagainya. Dengan berpandangan demikian pihak Belanda menjadi merasa yakin untuk mendominasi penduduk pribumi bahkan merasa sebagai pihak yang memperadabkan bangsa timur melalui cara eksploitasinya.

\section{Novel Mirah dari Banda sebagai Representasi Dominasi Militer Jepang}

Sistem kolonialisme Jepang yang berusaha mengeksploitasi Hindia Belanda secara dominatif tergambar jelas dalam novel $M d B$. Tokoh-tokoh perempuan pada masa kolonial Jepang dalam novel $M d B$ diuraikan mengalami nasib serupa seperti halnya pada masa penjajahan Belanda. Dalam beberapa hal bahkan mereka lebih menderita. Hal ini terbukti melalui kondisi tokoh Mirah yang semula menjadi nyai Tuan Besar kini semakin menderita dengan hidup terpencil di pengungsian, mengalami kelaparan dan kekurangan pakaian serta rentan terhadap kekerasan seksual yang dilakukan oleh penduduk pedalaman.

Selain itu, marak praktik pelecehan seksual terhadap perempuan oleh militer Jepang dengan menjadikanya sebagai perempuan penghibur atau jugun ianfu di markas militer Jepang. Sebagai jugun ianfu mereka tidak dapat lepas dari unsur penipuan, pemaksaan dan penindasan. Semula mereka dijanjikan untuk bersekolah di Tokyo, tetapi janji tersebut tidak pernah terwujud. Mereka justru dikirim ke Hollandia untuk dijadikan sebagai pemuas seksual militer Jepang. Sebagai jugun ianfu menerima perlakuan kejam tentara Jepang.
Serdadu yang datang biasanya bahkan memandang wajahnya pun tidak. Mereka langsung menyerbu tubuhnya dan mempersetan dunia di sekitar mereka.

(halaman 320-321)

Kutipan di atas jelas menunjukkan bahwa tentara Jepang menganggap jugun ianfu hanya sebatas sebagai objek pelampiasan seksual. Praktik ini menggambarkan kedudukan perempuan terjajah sebagai pihak yang tersubordinasi. Perlakuan demikian ternyata terkait erat dengan kelonggaran yang diberikan penguasa militer kepada pasukannya sebab hal yang diprioritaskan adalah kemampuan dan daya tahan mereka saat berada di medan perang. Oleh karena itu, apapun yang dapat membantu militer Jepang memenangkan perang akan diperbolehkan oleh pemerintah. Hal ini jelas menegaskan adanya kaitan antara penyediaan jugun ianfu dengan tujuan penguasaan (Juningsih, 1999:32).

Dengan demikian, tampak bahwa praktik kolonialisme Jepang membawa ideologi patriarkat. Hal ini terbukti pula melalui watak kemiliteran Jepang yang dijiwai tradisi samurai yang mencerminkan bangunan maskulin dengan ciri mempergunakan senjata dalam menyerang dan menundukkan perempuan. Setelah ditundukkan, perempuan hanya dipergunakan sebagai alas tidur (Rahayu, 1998:12). Dengan demikian, latar belakang munculnya penindasan ini ialah peliyanan atas perempuan negeri terjajah oleh militer Jepang serta kuatnya ideologi patriarki dan maskulinitas pada diri militer Jepang.

Ironisnya, dalam situasi demikian, lelaki pribumi pun ikut melakukan penindasan. Ia menjadi perantara pengambilan perempuan yang kelak dijadikan sebagai jugun ianfu. Dalam kisahnya terdapat seorang lelaki yang datang ke kampung Andano sebagai suruhan tentara Jepang. Status orang suruhan tersebut adalah penduduk pribumi. Ia bertugas mencari perempuan Belanda atau Indo yang melarikan diri di kampung-kampung pinggiran. 


\section{Jurnal Poetika Vol. IV No. 1, Juli 2016}

Kepala kampung sudah di muka pintu rumah pengungsian kami. Bersamanya turut dua tentara Jepang dan satu orang cokelat sebagai penunjuk jalan.

(halaman 268)

Kutipan di atas menunjukkan terdapatnya penduduk pribumi (satu orang cokelat) yang membantu militer Jepang dalam merekrut perempuan Indo. Pengetahuan penduduk pribumi mengenai lokasi kampungkampung pinggiran dimanfaatkan oleh militer Jepang untuk membantu mendapatkan para perempuan. Bantuan dari lelaki pribumi kepada militer Jepang tersebut membuat perempuan negeri jajahan mengalami dua penindasan secara tegas, yakni dari lelaki kolonial dan lelaki pribumi. Penindasan ganda ini mengakibatkan kaum perempuan menjadi semakin tidak berdaya dan terus terbungkam. Mereka semakin tidak memiliki ruang untuk mengemukakan suaranya.

\section{Ideologi Feminis Poskolonial dalam Imajinasi Pengarang}

Kehadiran novel $M d B$ pada tahun 1983 dengan kisah perempuan di era kolonialisme menunjukkan adanya kontinuitas ingatan masa lalu yang sulit untuk dilupakan. Bahkan dalam tingkatannya, kedudukan inferior perempuan yang ditampilkan novel $M d B$ tampak sesuai dengan fakta kedudukan perempuan di Hindia Belanda masa kolonialisme. Relevansi antara fakta dan fiksi ini menunjukkan bahwa novel $M d B$ telah berupaya menggambarkan kekuasaan kolonial berdasarkan pengalaman kolonisasi yang dirasakan oleh kaum perempuan, ia mewacanakan kolonialitas.

Representasi atas kedudukan perempuan demikian, tak hanya nampak dalam novel $M d B$ saja, melainkan juga nampak dalam beberapa novel lain. Dalam penelitian yang dilakukan oleh Sudibyo dkk (2010), diketahui bahwa novel Bumi Manusia dan Anak Semua Bangsa karya Pramoedya Ananta Toer mengangkat kasus nyai yang lemah dan rentan mengalami penindasan. Pramoedya dalam kedua novel memang menghadirkan nyai yang berbeda dengan mengubah stereotipe buruknya. Ia digambarkan sebagai sosok yang tegar, pekerja keras, bisa dipercaya, hemat, dan tekun belajar. Meski demikian, ketika berhadapan dengan kuasa kolonial dan patriarki sebagai sistem sosial yang dibangun berdasarkan dominasi laki-laki atas perempuan dan organisasi sosial yang menyeluruh yang secara sosial, politis, dan seksual memproduksi dan mereproduksi perempuan sebagai subordinasi laki-laki Nyai Ontosoroh menjadi rentan (Sudibyo, 2010:5). Sanikem dan Surati tokoh-tokoh novel tampak menjadi korban atas keserakahan ayahnya yang terobsesi dengan jabatan birokrasi kolonial. Mereka dijadikan sebagai alat barter oleh Ayahnya. Perjuangan yang mereka lakukan tak sanggup melawan, ia tetap membentur kuasa kolonial yang tak tergoyahkan.

Kehadiran karya-karya demikian di era pascakolonial menunjukkan adanya kontinuitas ingatan masa lalu yang sulit untuk pudar. Munculnya tema-tema ketertindasan perempuan di era kolonialisme sebagai kaum terbawah yang mengalami penindasan ganda merupakan "suara keras" yang selama ini tidak terdengar. Representasi ini kiranya sepakat dengan opini yang dikemukakan Gayatri Spivak dalam esainya "Can The Subaltern Speak?" bahwa dalam suasana dominasi terdapat kelompok inferior yang menjadi subjek hegemoni kelas-kelas yang berkuasa dalam kalangannya sendiri.

Pemahaman dan kesadaran mengenai realitas demikian menjadi perangsang para penulis novel untuk menghasilkan karya dengan tema perempuan dalam situasi kolonial. Strategi utama yang tentu dikedepankan dalam memahami kondisi kolonial adalah pemeriksaan ulang terhadap dikotomi-dikotomi penindasan, seperti "kolonial-antikolonial", "buruhmajikan”, "sipil-militer", “elite-subaltern” serta tak hanya memperhatikan "aktor-aktor luar", melainkan juga "aktor-aktor dalam" seperti keberadaan lelaki pribumi sendiri. Aktivitas demikian sekaligus menjawab pernyataan Spivak 


\section{Jurnal Poetika Vol. IV No. 1, Juli 2016}

bahwa kelompok-kelompok subaltern atau mereka yang tertindas memang sama sekali tidak bisa berbicara. Dengan demikian, kehadiran novel dengan tema dan perspektif demikian menjadi semacam agen bagi dirinya sendiri (perempuan bagi suara perempuan sendiri) untuk bersuara mengatasi keterbungkaman yang selama ini membelenggu.

\section{Refleksi di Era Kapitalisme}

Pertanyaan terakhir yang perlu dijawab adalah mengapa novel-novel tentang penindasan kolonial di era (Mirab dari Banda) muncul setelah Indonesia merdeka? Mengapa tema demikian tidak muncul saja ketika kolonialisme berlangsung sebagai bentuk resistensi nyata terhadap dominasi kolonialisme?

Jawaban atas pertanyaan ini terkait dengan kondisi dan sifat kolonialisme yang dominatif sehingga tidak memungkinkan para penulis untuk melakukan resistensi secara langsung. Artinya, kolonial secara nyata telah membungkam suara perlawanan dengan ancaman yang bersifat dominatif. Di sisi lain, kuatnya hegemoni kolonial yang secara sistematis menyatakan bahwa perempuan adalah makhluk liyan, rendahan, bodoh, tepat bekerja di sektor domestik terus menerus memproduksi pengetahuan bahwa perempuan harus berada di belakang laki-laki. Oleh karena itu, munculnya novel yang bersifat resistensi yang menggelorakan semangat kesadaran akan kebebasan merupakan efek nyata dari kemerdekaan.

Sementara itu, kehadiran novel dengan tema dan perspektif demikian tidaklah sematamata menunjukkan kebebasan bersuara saja, melainkan juga bermaksud untuk memberi ingatan nostalgia terhadap kekejaman kolonialisme. Novel dengan perspektif demikian merupakan jalan bagi kita sebagai generasi selanjutnya untuk melihat bentukbentuk realitas penindasan yang terjadi pada masa lalu. Bukan kemudian bermaksud untuk memunculkan sikap dendam untuk membalas, melainkan menumbuhkan kesadaran bahwa kolonialisme adalah satu kejahatan kemanusiaan besar. Sikap nostalgis terhadap penjajahan demikian semakin nyata jika kita membandingkannya dengan novel-novel karya NH Dini seperti Jepun Negerinya Hiroko (2000) dan Namaku Hiroko (1977). Dalam pembacaan secara komparatif dengan novel tersebut, akan tampak kemenduaan perspektif: jika pengarang novel membicarakan masa lalu mengenai sistem kolonialisme Jepang, maka ia akan menceritakan kekejaman penjajahan Jepang terhadap Indonesia. Akan tetapi, jika ia melihat Jepang saat ini (kontemporer), maka ia akan melihat Jepang adalah negara yang ramah, yang bersih, yang secara keseluruhan layak menjadi contoh bagi Indonesia. Artinya, ruang nostaligia menjadi ruang nyata bagi maksud utama kehadiran novel-novel yang berbau kekejaman kolonialisme (Sudibyo dkk, 2011).

Sementara itu, terkait dengan kondisi zaman sekarang, dimana globalisasi menjadi pertautanutamawarga dunia. Hierarkidominatif antara Barat dan Timur masih akan terus berlangsung. Sebagaimana yang dipaparkan oleh Leela Gandhi (2001:4), kolonialisme tidaklah berakhir dengan kolonialisme. Proses penguasaan tersebut mengalami perubahan bentuk tidak hanya bersifat pengendalian pada sarana sistem reproduksi material, melainkan bahkan bekerja lebih canggih dengan bergerak pada ranah mental dan terjadi dalam berbagai segi pranata kehidupan. Fenomena ini secara konkrit disebut sebagai imperialisme yang justru merupakan bentuk tertinggi dari kolonialisme.

Sepanjang pertengahan akhir abad 19 kapitalisme memasuki tahap tertinggi dengan ciri utamanya, yakni semangat kebebasan yang "padahal" secara tidak langsung menjadi pembenaran atas penguasaan yang bersifat monopolistik. Industrialisasi merupakan wujud nyata dari fenomena ini. Indonesia sebagai negeri jajahan secara strategis merupakan pasar potensial oleh negara-negara industri kapitalis, Eropa Barat, Amerika bahkan termasuk Cina. Berbagai produk kecantikan, konsep kecantikan, fashion, dan lain-lain menjelma menjadi kontruksi ideologis yang membekas dalam benak perempuan Indonesia. Konsep 


\section{Jurnal Poetika Vol. IV No. 1, Juli 2016}

kecantikan berupa kulit putih, langsing, dan sebagainya yang mengacu pada konsep perempuan barat kini kian mengedepan. Para perempuan pun berbondong-bondong mengikuti tren tersebut tanpa mencoba untuk mempertanyakan.

Kondisi demikian menyadarkan bahwa sebagai negeri bekas jajahan Indonesia takkan pernah bebas seutuhnya dari pengaruh penjajahan dalam bentuk apapun. Bahkan menurut Bhabha, negeri jajahan, akan sangat sulit lepas dari kultur si penjajah. Artinya, kehadiran novel yang bernafaskan resistensi yang membangkitkan kesadaran akan ketertindasan perempuan di era kolonialisme bukanlah semata-mata membicarakan permasalahan kolonialisme saja. Akan tetapi, merupakan refleksi untuk tetap waspada terhadap kekuasaan imperialisme yang di dalamnya memungkinkan adanya penindasan ganda (imperialisme dan patriarki) yang bersifat dominatif dan hegemonik dalam wujud-wujud yang lain.

\section{Kesimpulan}

Novel sebagai representasi atas realitas sosial menunjukkan situs-situs ideologi yang berpihak. Secara keseluruhan hadirnya novel $M d B$ merupakan usaha menghadirkan suara dirinya sendiri sebagai kaum inferior yang selama ini terbungkam. Berdasarkan analisis terhadap novel $M d B$ melalui perspektif feminisme poskolonial diketahui bahwa novel tersebut berusaha mewacanakan kedudukan inferior perempuan akibat dominasi sistem kolonialisme Belanda dan Jepang. Pada masa itu perempuan ditempatkan sebagai babu, nyai, kuli, jugun ian fu yang rentan terhadap kekejaman fisik. Di samping itu, munculnya peran pribumi sebagai perantara pihak kolonial dan beberapa kali ikut melakukan kekerasan seksual mengakibatkan perempuan pribumi semakin tertindas.

Pada dasarnya praktik penindasan ini terjadi karena latar belakang praktik penjajahan maupun sistem patriarki yang menggunakan ideologi maskulinitas, penstereotipan, dan pandangan liyan terhadap kaum perempuan di negeri terjajah. Oleh karenanya, para perempuan negeri terjajah secara jelas mengalami penindasan dari dua pihak, yakni sistem kolonialisme dan patriarki, lelaki kolonial dan lelaki pribumi, budaya patriarki asing dan patriarki pribumi. Dengan penindaan ganda ini mereka menjadi terus berada dalam posisi inferior, terbungkam tanpa memiliki ruang untuk berbicara.

Patut diperhatikan bahwa novel $M d B$ merupakan novel yang diterbitkan pada tahun 1983 dan diterbitkan kembali pada tahun 2010 sehingga novel ini merupakan novel yang lahir dalam situasi pascakolonial atau setelah kemerdekaan. Dengan demikian, novel ini merupakan novel nostalgia atas penindasan dan perjuangan pada masa kolonialisme. Terkait dengan kondisi globalisasi yang kuat akan dominasi kapitalisme kehadiran novel demikian menjadi semacam refleksi atas bentukbentuk penguasaan terhadap perempuan yang mungkin hadir dalam bentuknya yang lain yang tetap menempatkan perempuan dalam hierarki terendah di antara lelaki barat dan lelaki timur.

\section{Daftar Pustaka}

Ashcroft Bill, Gareth Griffiths, and Helen Tiffin. 1998. Key Concepts in Post-Colonial Studies. London: Routledge.

Bayy, Reggie. 2010. Nyai \& Pergundikan di Hindia Belanda. Diterjemahkan oleh Siti Hertina. Jakarta: Komunitas Bambu.

Eagleton, Terry. 2002. Marxisme dan Kritik Sastra. Diterjemahkan oleh Roza Muliati dkk. Yogyakarta: Penerbit Sumbu.

Gandhi, Leela. 2007. Teori Poskolonial Upaya Meruntubkan Hegemoni Barat. Diterjemahkan oleh Yuwan Wahyutri dan Nur Hamidah. Jakarta: CV Triarga Utama.

Hellwig, Tineke. 2007. Citra Kaum Perempuan di Hindia Belanda. Diterjemahkan oleh Mien Joebhaat. Jakarta: Yayasan Obor Indonesia. 
Jurnal Poetika Vol. IV No. 1, Juli 2016

Loomba, Ania. 2003. Kolonialismel Pascakolonialisme. Diterjemahkan oleh Hartono Hadikusumo. Yogyakarta: Bentang Budaya.

McLeod, John. 2000. Beginning Postkolonialism. Manchester: Manchaster University Press.

Mills, Sarra. 2009. "Teori Feminis Poskolonial" dalam Teori-Teori Feminis Kontemporer (ed. Stevi Jackson dan Jackie Jones). Yogyakarta: Jalasutra.

Onghokham. 1991. "Kekuasaan dan Seksualitas: Lintasan Sejarah Pra dan Masa Kolonial" dalam Prisma 7 Juli 1991. Yogyakarta.

Oyewumi, Oyeronke. 2005. "Coloniazing Bodies and Minds" dalam Postcolonialisms: An Anthology of Cultural Theory and Critism (ed. Desai, Gauraf and Supriya Nair.). Oxford: Berg.

Rambe, Hanna. 2010. Mirah dari Banda. Jakarta: Yayasan Pustaka Obor Indonesia.
Sianipar, Gading. 2004. "Mendefinisikan Pascakolonial?" dalam Hermeneutika Pascakolonial Soal Identitas (ed. Mudji Sutrisno). Yogyakarta: Kanisius.

Slemon, Stephen. 1995. "Unsettling the Empire: Resistance Theory for the Second World" dalam The Post-Colonial Studies Reader (ed. Bill Ashcroft). London: Routledge.

Spivak, Gayatri. 2010. Can the Subaltern Speak. New York: Columbia University Press

Sudibyo, dkk. 2010. "Representasi Perempuanperempuan Rentan dalam Novel Bumi Manusia dan Anak Semua Bangsa karya Pramoedya Ananta Toer: Kajian Feminisme Pascakolonial". Laporan Penelitian Fakultas Ilmu Budaya Universitas Gadjah Mada.

Sudibyo, dkk. 2011. "Kritik atas Praktik Dehumanisasi Fasisme Jepang dalam Novel Indonesia Dasawarsa 20002010". Laporan Penelitian Fakultas Ilmu Budaya Universitas Gadjah Mada. 